\title{
Characteristics of High Performance Organisations
}

\author{
André de Waal \\ Associate professor Maastricht School of Management, the Netherlands \\ Academic director HPO Center, the Netherlands \\ Havenstraat 29, 1211 KG Hilversum, the Netherlands \\ Tel: 31-35-603-7007_E-mail: andredewaal@planet.nl \\ Received: July 7, 2012 Accepted: July 25, 2012 Published: October 1, 2012 \\ doi:10.5296/jmr.v4i4.2062ＵRL: http://dx.doi.org/10.5296/jmr.v4i4.2062
}

\begin{abstract}
The recent economic downturn has caused tremendous upheaval in the business world. It has spurred many companies to self-analysis and further organisational improvement. As a result, there is an increasing interest into the factors that determine sustainable organisational success. Managers all over the world are trying out various improvement concepts, seeing mixed results. One likely reason for this is the lack of consensus on the organisational characteristics that lead to high performance. Another reason may be that research into high performance is predominantly conducted in US companies, making it seem less relevant to management practice outside the North American continent. The research study described in this article aims at identifying the factors which have a positive relation with organisational performance. Through review of 290 research studies into high performance and subsequent testing in 1470 organisations worldwide, 35 characteristics - grouped into five factors - were identified which have a correlation with high performance and seem to be generic. The research results provide managers with a framework that adds focus to their continuous improvement efforts.
\end{abstract}

Keywords: High performance Organisations, Excellence, Sustainability, Quality 


\section{Introduction}

According to Colvin (2009) the world changed fundamentally in 2007 when the credit crisis hit, eventually causing the most severe recession since the 1930s (Colvin, 2009). A wave of trends and developments, like globalization (Lawrence, 2002; Bakker et al., 2004; Starbuck, 2005; Schuster and Copeland, 2006; Sirkin et al., 2008; Ramamurti and Singh, 2009), new technology (Sadler, 2002; Malone, 2003; Light, 2005), ascension of Asian markets and especially India and China (Backman and Butler, 2007; Kamdar, 2007; Nath, 2008; Nobrega and Sinha, 2008), environmental issues (Rosen, 2000) and demographic shifts (Rosen, 2000; Martin, 2002), was hitting the business world at the same time as the credit crisis was going on and thus helped to reshape the global business economy. Many authors (Kely, 2006; Charan, 2009; Flatters and Willmott, 2009; Guth, 2009; Hagel et al., 2009; Kotler and Caslione, 2009) agree with Colvin but not all. Main critic is Mintzberg who finds that little has changed in the activities of managers between the 1970s and 19902 (Mintzberg, 1973, 2009). Apart from using new tools like e-mail, managerial work remained essentially the same. Mintzberg in turn is supported in his opinion that the fundamentals of the global business economy have not changed by Tengblad (2000, 2006), Hales (1996, 1999, 2000) and several other researchers (Watson, 2001, Tolmie et al. 2003). It seems that there is no consensus among researchers on whether or not business fundamentals have changed, leaving as yet the following question unanswered: 'What organisational or business models might be proposed, whether existing in the past or at present or drawn from scratch, as potential solutions to the problem of designing the firm for sustainable high performance in changing circumstances?' (Freeman and Zollo, 2009).

To find an answer on this question, we turned to research into factors that may explain long-term success of firms and which can be used to develop a framework for building sustainable organisations. In the wake of the landmark book In Search Of Excellence (Peters and Waterman, 1992) and the bestsellers Built To Last (Collins and Porras, 1994) and Good to Great (Collins, 2001), there has been a strong interest among academics and managers in identifying these high performance factors (O’Reilly III and Pfeffer, 2000; Hess and Kazanjian, 2006; Porras et all., 2007; Thoenig and Waldman, 2007; Gottfredson and Schaubert, 2008; Simons, 2008; Tappin and Cave, 2008; Spear, 2009). Research into factors that cause or facilitate high performance is driven by developments in the resource-based view of the firm (Lockett et al., 2009) and the theory of dynamic capabilities (Peteraf and Barney, 2003; Easterby-Smith et al., 2009; Teece, 2009). In the literature on the resource-based view and dynamic capabilities many different factors are identified as potentially important for high performance. The type of factors found seems to depend on the angle of research or the personal views and interests of the researchers what characteristics are found that will lead to the creation of a high performance organisation (HPO). This makes it difficult to define a set of factors which describes the HPO in general. It is therefore imperative that a clear HPO framework is developed to allow generalization (Pearson et al., 2008). The aim of this study was to identify factors that determine HPOs irrespective of context (for example country, industry, type of organisation, time period). The research question was formulated as follows: What are the factors, derived from empirical study, which have a positive correlation with the performance of organisations? These factors can 
guide managers as to which actions to take to lead their organisations to superior results. The results of this study can be presumed to create Management Theory because they originate from design science-based research which has as a mission "to develop knowledge that the professionals of the discipline in question can use to design solutions for their field problems" (Aken, 2005, p.20).

This study contributes to management research as the described review is one of the most extensive of its kind and takes a different root than previous research. The broad-based design of the study consisted of the fact that it involved literature from many different scientific disciplines, including organisational psychology, human resource management and strategic management, and the fact that the resulting framework was tested at many different types of organisations all over the world (Deshpandé et all., 2004; Aken, 2005). Much of the research on high performance so far has been done at US companies (Stadler, 2007), which may make the research results seem less relevant to management practice in non-Anglo-Saxon countries (Hofstede, 1980; Shao and Webber, 2006; Palrecha, 2009). This study distinguishes itself from these previous studies in that it, apart from North American studies, also included studies conducted in non-USA countries, and that the survey used in the study was administered to organisations in Europe, Asia, Africa and South-America). As opposed to many previous studies, no selection was made during this research as to the type of organisation, industry, country or time period to be studied, in order enable generalization. Many of the previous studies did not adhere to good scientific protocol because they beforehand explicitly made a selection of companies to study, thereby rendering the study outcomes of limited generic value (Niendorf and Beck, 2009; Resnick and Smunt, 2009).

This article is structured as follows. The first section describes the literature review. The purpose of this review was to identify possible factors that may have a positive correlation with HPOs based on previous research. This is followed by a discussion of the empirical study that was performed to validate the factors found during the literature review. The results of the empirical study, that is the identified HPO factors, are described in the third section, and extensively discussed in the fourth section. The article ends with the conclusion in which the limitations of the research and suggestions for further research are given.

\section{HPO research - Phase 1: literature review}

The first phase, the literature review, consisted of selecting the studies on high performance and excellence that were to be included in the empirical study. Criteria for including studies in the research were that the study: (1) was aimed specifically at identifying HPO factors or best practices; (2) consisted of either a survey with a sufficient large number of respondents so that its results could be assumed to be (fairly) generic, or of in-depth case studies of several companies so the results were at least valid for more than one organisation; (3) employed triangulation by using more than one research method (for example a questionnaire and interviews) (Jack and Raturi, 2006); and (4) there was written documentation containing an account and justification of the research method, research approach and selection of the research population, a clear analysis, and clear retraceable conclusions and results so that the quality of the research method could be assessed. 
The studies to be reviewed were gathered by searching the databases of Business Source premier, Emerald and Science Direct, and by browsing the internet with Google using the following search words: high performance, excellence, financial performance, organisational results, high performing organisations, high performance managers, high performance workforce, accountable organisation, adaptive enterprise, agile corporation, agile virtual enterprise, democratic enterprise, flexible organisation, high-performance work system, high reliability organisation, intelligent enterprise, real-time enterprise, resilient organisation, responsive organisation, robust organisation, and sustainable organisation. In addition, books were reviewed, mainly on business and management. The literature search was conducted in 2007 and it yielded 290 studies which satisfied all or some of the four criteria. The studies were grouped into three categories:

A. Studies which satisfied all four criteria. These studies formed the basis for the identification of the HPO characteristics. Category A comprised of 105 studies.

B. Studies which satisfied Criteria 1 and 2 but not Criterion 3 and Criterion 4only partly, because although the research approach seemed (fairly) thorough there is no clear description and justification of the method used. These studies provided additional input for the identification of HPO characteristics. Category B comprised of 66 studies.

C. Studies which satisfied Criteria 1 and 2 but not Criteria 3 and 4 , so there was no basis for generalizing the study findings. These studies were used as a reference to support the HPO characteristics that were identified in Category A and B studies. Category C comprised of 119 studies.

The content quality of the studies was not further evaluated because of the large number of studies (King and He, 2005). The 290 studies were summarized and put into two files by the author and two research assistants. The first file contained an overview of the studies that were reviewed, stating the (abbreviated) title of the research study, the author(s), the publication date, the research method(s) used, the research population, and the study category. To which category a study belonged was decided by the researcher who summarised that particular study. The study category was subsequently reviewed and approved by one of the other researchers. The second file described the research methods used, the research population, and the main findings of the study. In order to be able to classify the HPO characteristics, the framework of Kotter and Heskett (1992) was combined with that of Scott Morton (2003). These frameworks were used because their relatively simple set-ups made it easy to subdivide a large amount of information into factors. The Kotter and Heskett framework defined four factors which influence human behaviour in organisations: organisational culture; organisational structure (formal structure, systems, processes and policies); leadership of the organisation; and external orientation (competitors, public and legislative organisations). Scott Morton's framework enlarged the external environment factor by adding customers, suppliers and partners, and broadened the framework by adding a factor called 'individuals \& roles' and by adding strategy, organisational design and technology to the organisational structure factor. Each factor in the resulting framework determined the degree in which organisational members exhibit performance-driven behaviour, which reflected whether the organisation was a HPO or not (Waal, 2004). 


\section{MInstitute ${ }_{\text {Intm }}^{\text {Macrothink }}$}

Journal of Management Research

ISSN 1941-899X

2012, Vol. 4, No. 4

The identification process of the HPO-characteristics consisted of a number of steps. First elements were extracted from each of the 290 publications that the authors regarded as essential for high performance. These elements were then categorised in a matrix which listed all the factors included in the framework. Because authors used different terminologies in their publications, the elements were grouped according to similarity in categories under a factor and each group - later to be named 'characteristic'- was given an appropriate description. Subsequently, a matrix was constructed for each factor listing a number of characteristics. For the first 90 studies this process was reviewed and repeated by an external academic. The results of this academic review were extensively discussed with the author until agreement on the categorisation and the formulation of the characteristics was reached. Agreement was reached immediately in 95 percent of the cases, an additional 3 percent was reached quickly after clarifying some questions and mistakes, and the remaining 2 percent was reached after discussion. The outcome of the academic review provided sufficient ground to assume that the same categorisation process could be used for the remaining 200 studies. A total of 189 characteristics were identified. After that, the 'weighted importance' (i.e. the number of times a characteristic occurred in the individual study categories) was calculated for each of the characteristics. Finally, the characteristics with a weighted importance of at least nine percent were chosen as the HPO characteristics that potentially make up a HPO (see Appendix 1 for an example). Table 1 gives an overview of the resulting 53 potential HPO characteristics clustered in eight groups. The reference list with details about the 290 studies used in the review and the matrixes with the detailed scores have been documented in a white paper of 254 pages, which can be downloaded from http://papers.ssrn.com/sol3/papers.cfm?abstract_id=931873. The research approach thus satisfied the 'criteria for good science' as given by Srnka and Koeszegi (2007): the data collection was performed in a systematic way, there was a structured procedure and documentation of the data analysis, and there were multiple person involvement and quality checks.

Table 1 thus provides the two hypotheses to be tested during the empirical study:

H1. The 53 potential HPO characteristics, identified during the literature review, all have a positive correlation with competitive performance.

H2. The 53 potential HPO characteristics, identified during the literature review, will occur in practice grouped in the eight factors from the ordering framework.

Table 1. Overview of the 53 potential HPO characteristics, originating from the literature review

\begin{tabular}{|l|}
\hline Organisational design characteristics \\
\hline D1. Stimulate cross-functional and cross-organisational collaboration. \\
D2. Simplify and flatten the organisation by reducing boundaries and barriers between and around units. \\
D3. Foster organisation-wide sharing of information, knowledge and best practices. \\
D4. Constantly realign the business with changing internal and external circumstances. \\
\hline Strategy characteristics \\
\hline S1. Define a strong vision that excites and challenges. \\
\hline
\end{tabular}


S2. Balance long-term focus and short-term focus.

S3. Set clear, ambitious, measurable and achievable goals.

S4. Create clarity and a common understanding of the organisation's direction and strategy.

S5. Adopt the strategy that will set the company apart.

S6. Align strategy, goals, and objectives with the demands of the external environment and build robust, resilient and adaptive plans to achieve these.

Process characteristics

P1. Design a good and fair reward and incentive structure.

P2. Continuously innovate products, processes and services.

P3. Continuously simplify and improve all the organisation's processes.

P4. Create highly interactive internal communication.

P5. Measure what matters.

P6. Report to everyone financial and non-financial information needed to drive improvement.

P9. Strive for continuous process optimalization.

P8. Strive to be a best practice organisation.

P9. Deploy resources effectively.

Technology characteristics

T1. Implement flexible ICT-systems throughout the organisation.

T2. Apply user-friendly ICT-tools to increase usage.

Leadership characteristics

L1. Maintain and strengthen trust relationships with people on all levels.

L2. Live with integrity and lead by example.

L3. Apply decisive action-focused decision-making.

L4. Coach and facilitate.

L5. Stretch yourselves and your people.

L6. Develop effective, focused and strong leadership.

L7. Allow experiments and mistakes.

L8. Inspire the people to accomplish extraordinary results.

L9. Grow leaders from within.

L10. Stimulate change and improvement.

L11. Assemble a diverse and complementary management team and workforce.

L12. Be committed to the organisation for the long haul.

L13. Be confidently humble.

L14. Hold people responsible for results and be decisive about non-performers.

Individuals \& Roles characteristics

I1. Create a learning organisation.

I2. Attract exceptional people with a can-do attitude who fit the culture.

I3. Engage and involve the workforce.

I4. Create a safe and secure workplace.

I5. Master the core competencies and be an innovator in them.

I6. Develop people to be resilient and flexible.

I7. Align employee behaviour and values with company values and direction. 


\section{Ml Macrothink}

Culture characteristics

C1. Empower people and give them freedom to decide and act.

C2. Establish strong and meaningful core values.

C3. Develop and maintain a performance-driven culture.

C4. Create a culture of transparency, openness and trust.

C5. Create a shared identity and a sense of community.

External orientation characteristics

E1. Continuously strive to enhance customer value creation.

E2. Maintain good and long-term relationships with all stakeholders.

E3. Monitor the environment consequently and respond adequately.

E4. Choose to compete and compare with the best in the market place .

E5. Grow through partnerships and be part of a value creating network.

E6. Only enter new business that complement the company's strengths.

\section{HPO research - Phase 2: empirical study}

Phase 2 of the HPO research, the empirical study, was performed in two sub-phases. In Phase 2a, the 53 potential HPO characteristics were included in a trial questionnaire which was administered in 2005 during lectures and workshops given by the author in Europe and Africa. Purpose of the trail was to test the quality of the questionnaire and whether it was possible to find correlations between the characteristics identified during the literature review and the performance of organisations. The trial questionnaire yielded 116 respondents of 82 organisations. In the questionnaire the respondents indicated how well their organisations performed on the various HPO characteristics on a scale of 1 (very poor) to 10 (excellent) and also what their organisational results were compared to their peer group. Two types of competitive performance were established (Matear et al., 2004): (1) Relative Performance (RP) versus competitors: RP $=1-([R P T-R P W] /[R P T])$, in which RPT = total number of competitors and RPW = number of competitors with worse performance; (2) Historic Performance (HP) of the past five years (possible answers: worse, the same, or better). These subjective measures of organisational performance are accepted indicators of real performance (Dawes, 1999; Deshpandé et al., 2004; Devinney et al., 2005; Dollinger and Golden, 1992; Glaister and Buckley, 1998; Bae and Lawler, 2000; Heap and Bolton, 2004; Wall, 2004; Jing and Avery, 2008). With a statistical analysis (principal component analysis with oblimin rotation and non parametric Mann-Whitney test) of the respondents data, the characteristics which had the strongest correlation with organisational performance were extracted and identified as potential HPO characteristics. From the initial 53 characteristics nine did not show a statistically significant correlation with competitive performance so they were removed.

In Phase $2 \mathrm{~b}$, an updated questionnaire was constructed with the remaining 44 characteristics. The formulation of the characteristics was made more concise and comprehensible. In addition, the questionnaire was translated into other languages to accommodate respondents who were not proficient in English, and back-translated to validate the quality of the translations. The updated questionnaire was administered during courses, lectures, workshops 
and presentations given by the author and colleagues in Europe, North-America, Asia, Africa and South-America. The subject of these courses etc. was not always high performance; they also covered subjects such as performance management, budgeting, and organisational behaviour. There was therefore no bias in the respondent population. All respondents were working, some of them taking classes on the side, and no selection was made according to sex or age. The questionnaire, conducted in the period 2006 - beginning of 2007, yielded 2015 responses of 1470 organisations, which is an average of 1.4 respondents per organisation. Appendix 2 provides detailed information on the respondents and the organisations they worked at. Again, the data of the respondents was statistically analysed. In the first step of the statistical analysis a principal component analysis with oblimin rotation was performed. This yielded 40 characteristics with a loading higher than 0.300 , in 6 factors. These were then put in a non parametric Mann-Whitney test which resulted in 35 characteristics in 5 factors that showed a statistically significant correlation with competitive performance. The factor scales showed acceptable reliability (Hair et al., 1998) with Cronbach alpha values close to or above 0.60 .

There is a substantial difference in approach between the study described in this article and studies such as the ones carried out by Peters and Waterman (1982) and Collins (2001). In this study no selection was made in advance as to the objects or individuals that were to take part in the literature review and practical research in order to avoid bias and to make the probability of generalization (amongst others to the public sector) as high as possible (Aken, 2005). In the studies of the other researchers mentioned, and of many others, however, a selection was made in advance, on the basis of financial analyses; organisations that performed well or excellently in a certain sector were compared to competitors that did not perform as well. They then determined the distinguishing characteristics of excellence based on these comparisons. A point of criticism to the latter approach is that the fact that specific organisations were selected for inclusion in the studies could be interpreted as selection bias, which affects the generalization of these studies (Niendorf and Beck, 2008; Resnick and Smunt, 2008). To prevent selection bias, no selection was made during the research described in this article, not during the literature review (except for the fact that the studies had to be relevant and usable) nor during the empirical study (which included high, medium and low performing organisations).

\section{Results of Phase 2}

Many different definitions of HPOs can be found in the literature. They are often described in the sense of what they have achieved or consist of: strong financial results, satisfied customers and employees, high levels of individual initiative, productivity and innovation, aligned performance measurement and reward systems, and strong leadership (Collins and Porras, 1997; Geus, 1997; Brown and Eisenhardt, 1998; Hodgetts, 1998; Mische, 2001; Weick and Sutcliffe, 2001; Zook and Allen, 2001; Annunzio, 2004; Bruch and Ghoshal, 2004). As stated above, researchers approach the topic of high performance from different backgrounds and angles and with different goals. It is therefore not surprising that there is not a univocal definition of an HPO available yet. In this study, the definitions found in the Category A studies were combined to arrive at the following definition: A High Performance Organization is an organization that achieves financial and non-financial results that are 


\section{Macrothink}

Journal of Management Research

ISSN 1941-899X

2012, Vol. 4, No. 4

exceedingly better than those of its peer group over a period of time of five years or more, by focusing in a disciplined way on that what really matters to the organization.

\subsection{The HPO factors}

As mentioned above, the first step of the statistical analysis consisted of a principal component analysis with oblimin rotation. This analysis yielded 40 characteristics with a loading higher than 0.300, in six factors (see Table 2 and Appendix 3 for further details).

Table 2. Overview of the six potential HPO factors and accompanying 40 potential HPO characteristics, resulting from the principal component analysis (items 31 and 41 load on two factors; items 32, 33, 35 and 40 do not load on any factor)

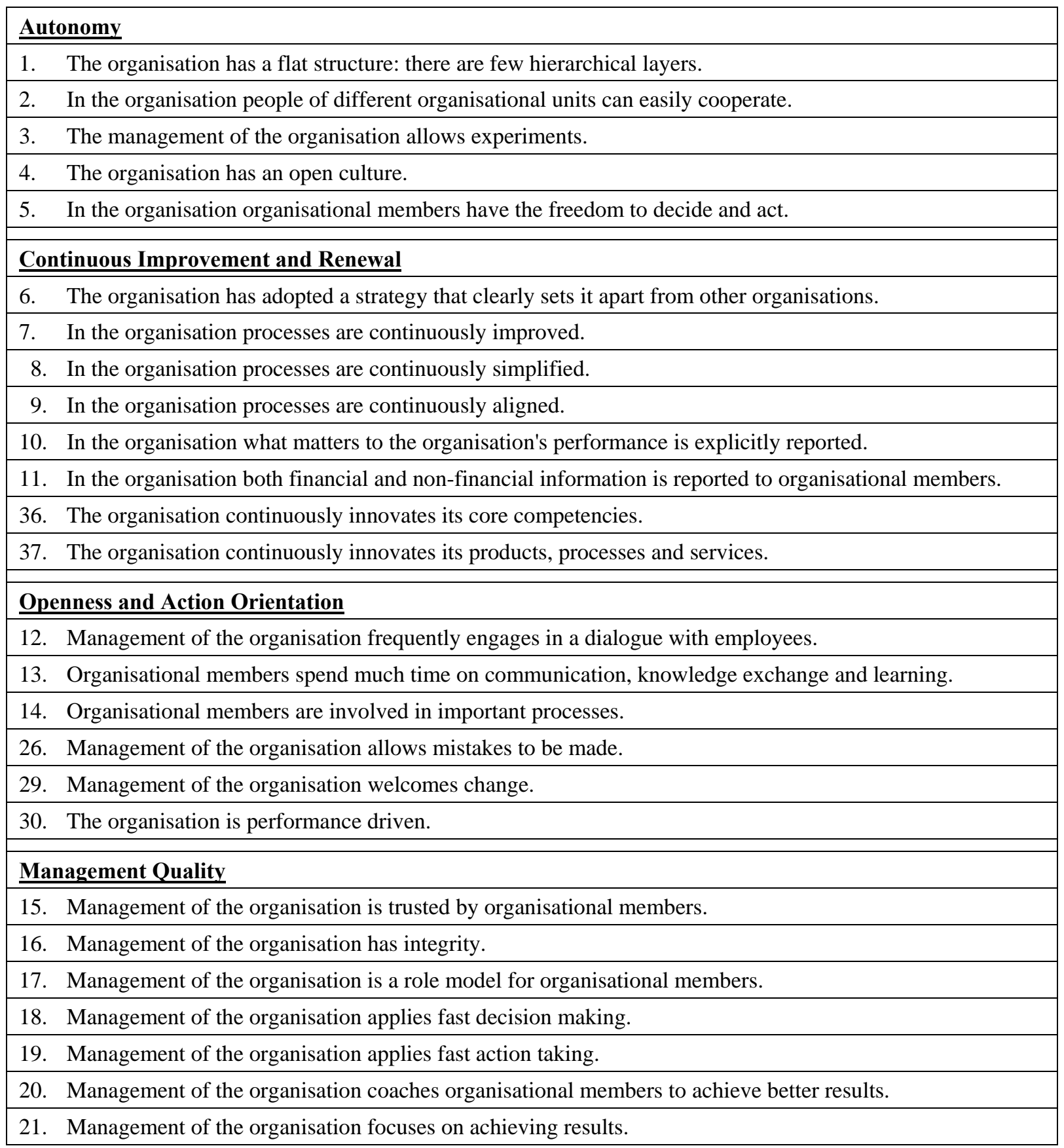


22. Management of the organisation is very effective.

23. Management of the organisation applies strong leadership.

24. Management of the organisation is confident.

25. Management of the organisation is decisive with regard to non-performers.

31. The management of the organisation always holds organisational members responsible for their results.

\section{Workforce Quality}

27. The management of the organisation inspires organisational members to accomplish extraordinary results.

28. Organisational members are trained to be resilient and flexible.

31. The management of the organisation always holds organisational members responsible for their results.

34. The organisation has a diverse and complementary workforce.

41. The organisation grows through partnerships with suppliers and/or customers.

\section{Long-Term Orientation}

38. The organisation maintains good and long-term relationships with all stakeholders.

39. The organisation is aimed at servicing the customers as best as possible.

41. The organisation grows through partnerships with suppliers and/or customers.

42. Management of the organisation has been with the company for a long time.

43. New management is promoted from within the organisation.

44. The organisation is a secure workplace for organisational members.

In order to verify whether the potential HPO factors were correlated with competitive performance, a correlation matrix was constructed. As Table 3 shows five of the six factors correlated with Relative Performance (RP) and Historical Performance (HP). As the potential HPO factor 'Autonomy' did not show a correlation with RP and only a weak correlation with HP, it was eliminated as an HPO factor. Interestingly, the correlation with HP was a negative one, which indicates that too much autonomy has a negative effect on performance. It seems that a certain degree of coordination and control in the organisation is required for being competitive.

Table 3. Correlation between potential HPO factors and competitive performance (Relative Performance and Historical Performance)

\begin{tabular}{|l|l|l|l|l|}
\hline & $\underline{\text { Relative }}$ & $\underline{\text { Performance }}$ & Historic & Performance \\
\cline { 2 - 5 } & Correlation & Significance & Correlation & Significance \\
\hline \multirow{2}{*}{ Autonomy } & -.040 & .412 & -.124 & .012 \\
\hline Continuous Improvement and Renewal & $\mathbf{. 2 1 2}$ & .000 & $\mathbf{. 2 9 9}$ & .000 \\
\hline Openness and Action Orientation & $\mathbf{. 1 6 5}$ & .001 & $\mathbf{. 1 3 7}$ & .006 \\
\hline Management Quality & $\mathbf{. 2 4 8}$ & .000 & $\mathbf{. 2 8 9}$ & .000 \\
\hline Workforce Quality & $\mathbf{. 2 2 7}$ & .000 & $\mathbf{. 1 5 1}$ & .002 \\
\hline Long-Term Orientation & $\mathbf{. 3 2 7}$ & .000 & $\mathbf{. 3 3 3}$ & .000 \\
\hline
\end{tabular}




\section{MInstitute ${ }^{\text {Mech }}$}

Journal of Management Research

ISSN 1941-899X

2012, Vol. 4, No. 4

The HPO factor Continuous Improvement and Renewal showed a correlation of .212 with Relative Performance and a slightly stronger correlation of .299 with Historical Performance. This factor is very much in line with continuous improvement and innovation, a trend which has been keeping organisations occupied for the past two decades.. To improve and innovate, an HPO usually starts with adopting a unique strategy that will set the organisation apart by developing new options and alternatives to compensate for strategies that are running out of steam. After that, the organisation will do everything in its power to fulfil this strategy. It continuously simplifies, improves and aligns all of its processes to improve the ability to respond to events both efficiently and effectively and to eliminate unnecessary procedures, work, and information overload. The organisation measures and reports everything that is relevant by constantly monitoring progress and goal fulfilment. It makes this information known to not only management but to everyone in the organisation, giving all organisational members the financial and non-financial information they need to drive improvement. People in a HPO feel a moral obligation to continuously strive for the best results. The organisation continuously innovates products, processes and services thereby constantly creating new sources of competitive advantage by rapidly developing new products and services to respond to market changes. It also masters its core competencies and is an innovator in them by deciding and sticking to what the company does best, keeping core competencies inside the firm and outsourcing non-core competencies.

The HPO factor, Openness and Action Orientation, showed a correlation of .165 with Relative Performance and a slightly weaker correlation of .137 with Historical Performance. In comparison to the other four HPO factors, this factor has the weakest correlation with competitive performance, which means that an open and action-oriented culture is relatively less important to the other factors when achieving high performance. This factor concerns characteristics that not only create an open culture in the organisation but also focus on using the openness to take dedicated action to achieve results. Management values the opinion of employees by frequently engaging in a dialogue with them and by involving them in all important business and organisational processes. HPO management allows experiments and mistakes by permitting employees to take risks, being willing to take risks themselves, and seeing mistakes as opportunities to learn. In this respect, management welcomes and stimulates change by continuously striving for renewal, developing dynamic managerial capabilities to enhance flexibility, and being personally involved in change activities. People in an HPO spend a lot of time on communication, knowledge exchange and learning in order to obtain new ideas to do their work better and make the complete organisation performance-driven.

The HPO factor Management Quality showed a correlation of .248 with Relative Performance and a slightly stronger correlation of .289 with Historical Performance. The quality of managers is the second most important factor for achieving high performance. In an HPO management combines many characteristics. It maintains trust relationships with people on all organisational levels by valuing employees' loyalty, treating smart people smart, showing people respect, creating and maintaining individual relationships with employees, encouraging belief and trust in others, and treating people fairly. Managers of a HPO live with integrity and are a role model by being honest and sincere, showing commitment, 
enthusiasm and respect, having a strong set of ethics and standards, being credible and consistent, maintaining a sense of vulnerability and by not being self-complacent. They apply decisive, action-focused decision-making by avoiding over-analysis and coming up with decisions and effective actions. At the same time they foster action-taking by others. HPO managers coach and facilitate employees to achieve better results by being supportive, helping them, protecting them from outside interference, and by being available. Management holds people responsible for results and is decisive about non-performers by always focusing on the achievement of results, maintaining clear accountability for performance, and making tough decisions. Managers of a HPO develop an effective, confident and strong management style by communicating the values and by making sure the strategy is known and embraced by all organisational members.

The HPO factor Workforce Quality showed a correlation of .227 with Relative Performance and a weaker correlation of .151 with Historical Performance It means that the quality of employees is an important, yet slightly less important factor for achieving high performance than management quality is. A HPO makes sure it assembles a diverse and complementary workforce. It recruits a workforce with maximum flexibility to help detect the complexities in operations and to incite creativity in solving them. A HPO continuously works on the development of its workforce by training them to be both resilient and flexible, letting them learn from others, inspiring them to improve their skills to accomplish extraordinary results, and holding them responsible for their performance to stimulate them to look for new productive ways to achieve the desired results.

The fifth factor, long term orientation showed a correlation of 327 with Relative Performance and. 333 with Historical Performance. In comparison to the other four HPO factors, this factor has the strongest correlation with competitive performance. This means that focussing on the long term is the most important trait for achieving high performance. In an HPO long-term commitment is extended to all stakeholders of the organisation, which comprise not only shareholders but also employees, suppliers, clients and the society at large. A HPO continuously strives to enhance customer value creation by learning what customers want, and understanding their values. A HPO builds excellent relationships with them by having direct contact with them, engaging them, being responsive to them, and focusing on continuously enhancing customer value. A HPO maintains good and long-term relationships with all stakeholders by networking broadly, being generous to society, and creating mutual, beneficial opportunities and win-win relationships. A HPO also grows through partnerships with suppliers and customers, thereby turning the organisation into an international network corporation. Management of a HPO is committed to the organisation for the long haul by balancing common purpose with self-interest, and teaching organisational members to put the needs of the enterprise as a whole first. They grow new management from the own ranks by encouraging people to become leaders, filling positions with internal talent, and promoting from within. A HPO creates a safe and secure workplace by giving people a sense of safety (physical and mental) and job security and by not immediately laying off people, only as a last resort.

It is interesting to see what techniques and methods do not seem to help an organisation in becoming and staying a HPO. This was evaluated by looking at the original 189 
characteristics identified from the 290 HPO studies during the literature review and comparing these with the 35 characteristics which showed a significant correlation with competitive performance. It turned out that none of the characteristics concerning organisational designs and structures showed a correlation with high performance and therefore seem to be non-decisive for organisational performance. It thus seems that as performance is concerned it makes no difference whether management chooses a functional design, a process design or a matrix design. Consequently, starting a reorganisation to boost performance is probably not recommended. Similarly more empowerment of staff may not necessarily contribute to high performance. The research results showed that a high level of autonomy had a negative correlation with competitive performance (factor 1 in Appendix 3). Too much freedom of employees could lead to internal disorder and confusion if it is not backed up with sufficient means of coordination and can seriously damage an organisation. Another interesting outcome of the research was that it is not so much the chosen organisational strategy that is important (as all characteristics concerning cost leadership, product differentiation and customer intimacy strategies were not significant) but the uniqueness of the strategy compared to competitors in the same industry. Adopting merely a 'me-too' strategy is not enough to become a HPO. A third outcome was the ineffectiveness of stand-alone implementation of information and communication (ICT) systems. Many organisations spend a lot of time and resources on implementing new ICT systems but this will not necessarily make them HPOs. Although many of the characteristics (especially of continuous improvement) cannot or barely be improved without ICT systems, the stand-alone implementation of new systems and technology does not help the organisation perform any better; the implementation has to support at least one of the HPO factors. Finally, the study showed that benchmarking was less effective than expected (as item 40 did not load on any of the factors). When an organisation embarks on a benchmarking project it usually aims to identify best practices, emulate these and attain the same level as the industry's best. HPOs, however, have a completely different view on best practices. They regard competitors' best performance merely as the baseline for performance, a starting point from which HPOs distance themselves as much as possible.

\subsection{Best versus worst performers}

To test whether organisations with a high HPO score showed better performances than organisations with a low HPO score, we divided the respondents in three groups according to their Relative Performance (RP) score. Group 1 had a RP below 0.33, Group 2 a score between 0.34 and 0.65 , and Group 3 a score above 0.66 . Using T-tests for differences in group means between Groups 1 (low) and 3 (high), we found statistically significant differences between these groups for the five HPO factors $(p<0.000)$, but not for the factor Autonomy. Table 4 gives the statistics. These show that the biggest difference can be found in the HPO factor Long-Term Orientation, meaning that HPOs pay considerably more attention to the aspects belonging to this factor than non-HPOs do. This also holds true for the other factors, except for Autonomy which shows that better performing organisations give less autonomy (the mean for Group 3 is more negative than for Group 1). 
Table 4. T-test of the differences between respondent groups

$(1=\mathrm{RP}$ score $<0.33 ; 3$ = RP score $>0.66)$

\begin{tabular}{|l|l|l|l|l|l|}
\cline { 2 - 6 } \multicolumn{1}{c|}{} & $\begin{array}{l}\text { RP } \\
\text { group }\end{array}$ & $\mathbf{N}$ & Mean & $\begin{array}{l}\boldsymbol{\Delta} \\
\mathbf{( 3 - 1 )}\end{array}$ & $\begin{array}{l}\text { Sign. } \\
\text { (2-tailed) }\end{array}$ \\
\hline Autonomy & 1 & 100 & -.071 & .079 & .514 \\
& 3 & 242 & -.150 & & .534 \\
\hline Continuous Improvement & 1 & 100 & -.200 & .545 & .000 \\
And Renewal & 3 & 242 & .345 & & .000 \\
\hline Openness and & 1 & 100 & -.075 & .539 & .000 \\
Action Orientation & 3 & 242 & .464 & & .000 \\
\hline Management & 1 & 100 & -.367 & .716 & .000 \\
Quality & 3 & 242 & .349 & & .000 \\
\hline Workforce & 1 & 100 & -.278 & .523 & .000 \\
Quality & 3 & 242 & .245 & & .000 \\
\hline Long-Term & 1 & 100 & -.303 & .801 & .000 \\
Orientation & 3 & 242 & .498 & & .000 \\
\hline
\end{tabular}

\subsection{Clustering}

To test whether the HPO factors were correlated with each other, a correlation matrix was constructed. Table 5 shows that all factors were correlated with each other, meaning that when an organisation works on improving one of the factors, the other factors will also be improved. Thus the HPO framework may be denoted to be a system of complementary (Milgrom and Roberts, 1990, 1995) in which the return on one HPO factor becomes higher in the presence of the other HPO factors. Thus an organisation should concentrate not on improving one HPO factor but on all of them to receive maximum benefit for the HPO framework.

Table 5. Correlation matrix of the HPO factors

( $\mathrm{N}=1740$; all correlations are significant at the 0.01 level, 2-tailed)

\begin{tabular}{|l|l|l|l|l|l|l|}
\cline { 3 - 7 } \multicolumn{2}{c|}{} & MQ & OAO & LTO & CI & WQ \\
\hline Management & Correlation & 1 & .391 & .378 & .527 & .348 \\
Quality (MQ) & Significance & & .001 & .000 & .000 & .000 \\
\hline $\begin{array}{l}\text { Openness and Action } \\
\text { Orientation (OAO) }\end{array}$ & Correlation & & 1 & .317 & .367 & .110 \\
\hline Long Term & Significance & & & .000 & .000 & .000 \\
Orientation (LTO) & Correlation & & & 1 & .324 & .209 \\
\hline $\begin{array}{l}\text { Continuous } \\
\text { Improvement (CI) }\end{array}$ & Significance & & & & .000 & .000 \\
\hline
\end{tabular}




\subsection{Profit versus non-profit versus government}

The Bonferroni test was used to evaluate whether there were statistically significant differences in HPO factor scores between the profit, non-profit and government sectors. Table 6 gives per HPO factor the significant differences and the mean and average scores.

Table 6. Differences between sectors and correlations with relative performance (correlations are significant at the $0.00[* * *], 0.01\left[^{* *}\right]$ or $0.05[*]$ levels, 2-tailed)

\begin{tabular}{|l|l|l|l|l|}
\cline { 2 - 5 } \multicolumn{1}{c|}{} & Sector & $\begin{array}{l}\text { Mean } \\
\text { scores }\end{array}$ & $\begin{array}{l}\text { Significant } \\
\text { differences }\end{array}$ & $\begin{array}{l}\text { Correlation } \\
\text { with RP }\end{array}$ \\
\hline Management & Profit & .110 & a. Profit-Non profit*** & $.198^{* *}$ \\
Non profit & -.375 & b. Profit- Government** & \\
& Government & -.099 & c. Non profit - Government*** & $.330^{* *}$ \\
\hline Openness and & Profit & .001 & & $.121^{* *}$ \\
Oction & Non profit & .086 & a. Non profit - Government* & $.171^{*}$ \\
\hline Long Term & Government & -.114 & & \\
Committment & Profit & .097 & a. Profit-Non profit*** & $.227^{* *}$ \\
& Non profit & -.232 & b. Profit- Government*** & $.230^{* *}$ \\
\hline Continuous & Government & -.240 & & $.170^{* *}$ \\
Improvement & Profit & -.003 & & $.200^{*}$ \\
\hline Workforce & Non profit & .022 & & $.153^{* *}$ \\
\hline Quality & Government & -.049 & & \\
\hline
\end{tabular}

Table 6 shows that the quality of management in the profit sector is perceived to be significantly higher than in the other two sectors, and that management quality in government is higher than in the non-profit sector. It also shows that the quality of the workforce is higher and that there is a higher long-term orientation in the profit sector than in the other two sectors. There is also significantly more openness and action orientation in the non-profit sector than in government. The table also shows that organisations in the profit sector need to focus on all five HPO factors simultaneously to become and stay an HPO, while non-profit organisations first need to focus on Openness and Action Orientation, Long-Term Orientation, and Continuous Improvement and Renewal before working on the remaining factors. Finally, governmental agencies need to focus especially on Management Quality.

\section{Discussion}

The research question dealt with in this paper was formulated as follow: What are the factors, derived from empirical study, which have a positive correlation with the performance of organisations? The research yielded 35 characteristics distributed over five factors which have the most impact on high performance, and thus together can be designated as a HPO framework. As such, this HPO framework could be the organisational model many 
organisations are looking for to achieve economic, environmental and social sustainability (Freeman and Zollo, 2009). In regard to the formulated hypotheses, it was concluded that hypothesis 1 - The 53 potential HPO characteristics, identified during the literature review, all have a positive correlation with competitive performance - could be accepted as only 35 characteristics showed a positive correlation. Most of the studies into high performance done previously limited themselves to one or a few countries and one or a limited number of industries (Waal, 2012) and thus yield many distinctive characteristics. It can be assumed, however, that the more generic the outcomes looked for, such as in this study, the less factors turn out to be valid. This could explain that 18 characteristics turn out to not have a significant correlation. Hypothesis 2 - The 53 potential HPO characteristics, identified during the literature review, will occur in practice grouped in the eight factors from the ordering framework - could also not be accepted as the 35 characteristics did appeared to be distributed over five factors instead of eight.

In the literature review and the questionnaire no distinction was made as to the types of organisations, industries, countries and time periods) that were to be included in the research. The raises the question whether the HPO framework which resulted from this study is generic: Is it potentially suitable for all types of organisations worldwide? One may argue that the data collected in this study were incomparable because of the wide variety of studies, organisations, industries and countries involved. In a sense this question is connected to the etic-emic debate, where the etic approach argues that theories are universal while the emic approach claims that these are culture or context specific (Morris et al, 2000; Lamond et al., 2001; Jayakody, 2008). Instead of the terms etic and emic, Morrison (2000) used the terms generalizable and idiosyncratic. Generalization is defined as "the derivation of and argumentation for conclusions covering many or all cases of a certain type based on one or more observations of the real world" with the generalized conclusion taking shape as a "conceptual framework[s], which offers us the possibility to discuss the subject area in general” (Lukka and Kasanen, 1995, p. 72). The first remark to be made in this respect is that the researched phenomena, the performance of HPOs, sits in the social world. And, as Aken (2005, p. 31) remarks, "In this social world there are no universal mechanisms, human consciousness and reflexivity make general laws impossible. But there are observable stable patterns in social phenomena, which are reproduced by human conduct, consciously or unconsciously, and supported by stable shared knowledge and beliefs. Such stable patterns can be used as the basis for general statements.” This is supported by Cheng (1994) and Humprey and Scapens (1992), who see the possibilities of some structures containing regularities across institutions. As such, the HPO framework can be seen as a stable pattern. Second, in the growing research stream on globalization there is an increasing number of observations that the transfer of management techniques from one country to the other is leading to similar patterns of behaviour across these countries and thus to similar characteristics of importance for high performance (Davidson et al., 1976; Bowman et al., 2000; Deshpandé et al., 2000; Stede, 2003; Zagersek et al., 2004; Costigan et al., 2005). The developed HPO framework contains characteristics that potentially are applicable in various settings and contexts. Third, in the constructive research approach a business problem is solved in one or more case organisations by developing a new solution that also has a 
scientific contribution (Lukka and Kasanen, 1995). In constructive generalization rhetoric the successful implementation of the new solution - in this case the characteristics as found in the organisations researched in the 290 studies - makes it plausible that the solution - the HPO framework- will also work in other organisations. It can be stated that the generalization of the HPO framework is, in the topology of Lee and Baskerville (2003), a type TT generalizability where the formulation of a theory (in this case the HPO framework) is based on the synthesis of ideas from a literature review (Lee and Baskerville, 2003, p. 238). It is, however, possible that the manner in which the HPO characteristics are improved does depend on the context, in this case the national culture, industry, organisational culture and even the experiences and skills of the individuals executing the improvements (Hofstede, 1980).

The significance of this study into HPOs is that once the HPO factors are known, management can determine the HPO status of the organisation and identify required improvements. This could be done by distributing the questionnaire used in Phase 2 (after removing the characteristics which did not show a correlation with competitive performance) among managers and other staff, to identify the HPO status of the organisation. The detailed scores on the HPO factors will reveal both the strengths and the improvement points of the organisation and will set the action agenda for the transition to HPO.

\section{Conclusion}

There are several limitations to this study. Despite the fact that the literature search was extensive, potentially valuable studies may have been overlooked. In this respect, also it should be noted that predominantly published studies were taken into account, which creates a potential bias as unpublished studies may contain different outcomes (Asworth et al., 1992). The study did however include a number of working papers, originating from the Social Sciences Research Network and collected during conferences. Another potential bias is the presence of subjectivity in the choice of literature sources that were included in the study (Asworth et al., 1992). This problem has been alleviated by including literature from many different disciplines during the selection process. As the findings are based upon scores from a single source, namely the respondents' perceptions of the factors of high performance and competitive performance, another limitation is introduced. Common-method bias may have inflated the correlations, although the magnitude of such effects is subject to intense debate (Crampton and Wagner 1994; Podsakoff et al., 2003). Most researchers agree that potential risks can be reduced by careful questionnaire design (for example anonymity and encouraging participants' openness) which the researcher paid specific attention to by testing the questionnaire during Phase 2a and by stressing specifically the anonymity of the questionnaire.

As is always the case with research based on a questionnaire and self-reported scores, there is the possibility of attribution. Is it possible that the respondents reporting high performance and those reporting low performance make implicit attributions of characteristics, and in fact, causation. That is, they look for response choices that confirm their view of why the organisation is either high or low performing compared to the peer group. Ideally, the research should be based on identifying the respondents' organisations and then making an independent assessment of Relative Performance and Historical Performance from 
industry-wide data. In practice this however is impossible with a study on this grand and worldwide a scale. In regard to the issue of generalization, we have to take note of Lukka and Kasanen's (1995) remark that "all attempts to make empirical generalizations are inevitably inductive by nature" and thus "we can never be sure whether our reasoning preserves truth or not, as is possible in the case of induction." Also, Martin et al. (1983) state that for generalization companies fundamentally have to be quite similar. Although many institutions worldwide are growing similar in the way they are managed, it still cannot be stated with certainty that they are similar in nature. The studies used in the research look by definition on what organisations have done in the past, therefore not necessarily giving a guarantee that these characteristics will also be valid for the dynamic future (Morton, 2003). The results of this research therefore have to be seen, not as instructions or recipes to follow, but as design exemplars (Aken, 2005) which have to be translated by practitioners to their specific situation in time by designing a specific variant of the exemplar. The studies used in the literature review look by definition on what organisations have done in the past and can therefore not necessarily give a guarantee that these characteristics will also be valid for the dynamic future (Morton, 2003). At the same time, if the reasoning of Mintzberg (2009) is followed that the work of managers has not changed significantly over time, it is a reasonable assumption especially because so many of the HPO characteristics have to do with management - that the HPO factors are still valid for the foreseeable future.

Further research should focus on validating the HPO factors in even more countries and industries. Also, additional research should focus on the "how" now that the "what" is known. The HPO framework stipulates "what" is important to become and stay successful but is does not indicate "how" organisations can achieve success. So future research should concentrate on identifying, collecting and describing "best ideas" of organisations who have achieved success in some or maybe all of the HPO factors. Finally, the ever present issue of causality should be further investigated to answer the question whether HPOs have the time and resources to foster the characteristics of high performance, or whether the characteristics create a HPO.

\section{References}

Aken, J.E. van (2005). Management research as a design science: articulating the research products of mode 2 knowledge production in management. British Journal of Management, 16: 19-36. http://dx.doi.org/10.1111/j.1467-8551.2005.00437.x

Annunzio, S.L. (2004). Contagious success. Spreading high performance throughout your organisation. Portfolio Penguin Books, London

Ashworth, S.D., H.O. Osburn, J.C. Callender, \& K.A. Boyle (1992). The effects of unrepresented studies on the robustness of validity generalization results. Personnel Psychology, 45: 341-360. http://dx.doi.org/10.1111/j.1744-6570.1992.tb00853.x

Backman, M., \& C. Butler (2007). Big in Asia, 30 strategies for business success. Palgrave MacMillan. Basingstoke

Bae, J., \& J.J. Lawler (2000). Organisational and HRM strategies in Korea: impact on firm performance in an emerging economy. Academy of Management Journal, 43, 3: 502-517. http://dx.doi.org/10.2307/1556407 
Bakker, H.J.C., M.N.F. Babeliowsky, \& F.J.W. Stevenaar (2004). The next leap. Achieving growth through global networks, partnerships and cooperation. Cyan Books, London

Becker, B.E., \& M.A. Huselid (1998). High performance work systems and firm performance. A synthesis of research and managerial implications. Research in Personnel and Human Resources Management, 16: 53-101

Bolton, D. (2004). Change, coping and context in the resilient organisation. Mt Eliza Business Review, 7, 1: 56-66

Bowman, D., J.U. Farley, \& D.C. Schmittlein (2000). Cross-national empirical generalization in business services buying behavior. Journal of International Business Studies, 31, 4: 667-685. http://dx.doi.org/10.1057/palgrave.jibs.8490928

Brown, S.L., \& K.M. Eisenhardt (1998). Competing on the edge. Strategy as structured chaos. Harvard Business School Press, Boston

Bruch, H., \& S. Ghoshal (2004). A bias for action. How effective managers harness their willpower, achieve results, and stop wasting time. Harvard Business School Press, Boston Charan, R. (2009). Leadership in the era of economic uncertainty, McGraw-Hill: New York Cheng, J.L.C. (1994). Notes: on the concept of universal knowledge in organisational science: implications for cross-national research. Management Science, 40, 1: 162168

Collins, J. (2001). Good to great. Why some companies make the leap ... and others don't. Random House. London

Collins, J.C., \& J.I. Porras (1994). Built to last. Successful habits of visionary companies. Harper Business, New York

Colvin, G. (2009). The Upside of the Downturn. 10 Management strategies to prevail in the recession and thrive in the aftermath. Nicholas Brealey Publishing, London

Costigan, R.D., R.C. Insinga, J.J. Berman, S.S. Ilter, G. Kranas, \& V.A. Kureshov (2005). An examination of the relationship of a Western performance-management process to key workplace behaviours in transition economies. Canadian Journal of Administrative Sciences, 22, 3: 255-267. http://dx.doi.org/10.1111/j.1936-4490.2005.tb00370.x

Coulson-Thomas, C. (1996). The responsive organisation: re-engineering new patterns of work. Management Services, 40, 7: 14-15

Crampton, S.M., \& Wagner, J.A. (1994). 'Percept-percept inflation in micro-organisational $\begin{array}{llll}\text { research'. Journal of Applied Psychology, } & \text { 79, }\end{array}$ http://dx.doi.org/10.1037/0021-9010.79.1.67

Dalziel, M., S. DeVoge, \& K. LemAire (2004). Six principles for designing the accountable organisation. Journal of Organisational Excellence, Autumn: 59-66. http://dx.doi.org/10.1002/npr.20027

Davidson, A.R., J.J. Jaccard, H.C. Triandis, M.L. Morales, \& R. Diaz-Guerrero (1976). Cross-cultural model testing: toward a solution of the etic-emic dilemma. International Journal of Psychology, 11, 1: 1-13. http://dx.doi.org/10.1080/00207597608247343

Dawes, J. (1999). The relationship between subjective and objective company performance measures in market orientation research: further empirical evidence. Marketing Bulletin, 10: 65-76 


\section{Al Macrothink}

Journal of Management Research ISSN 1941-899X 2012, Vol. 4, No. 4

Deshpandé, R., J.U. Farley, \& F.E. Webster Jr. (2000). Triad lessons: generalizing results on high performance firms in five business-to-business markets. International Journal of Research in Marketing, 17: 353-362. http://dx.doi.org/10.1016/S0167-8116(00)00009-4

Deshpandé, R., J.U. Farley, \& D. Bowman (2004). Tigers, dragons, and others. Profiling high performance in Asian firms. Journal of International Marketing, 12, 3: 5-29. http://dx.doi.org/10.1509/jimk.12.3.5.38101

Devinney, T.M., Richard, P.J. ,Yip, G.S. \& Johnson, G. (2005). Measuring organisational performance in management research: a synthesis of measurement challenges and approaches. Research paper, www.aimresearch.org , accessed February $14^{\text {th }}, 2008$

Dollinger, M.J., \& Golden, P.A. (1992). Interorganisational and collective strategies in small firms: environmental effects and performance. Journal of Management, 18, 4: 695-715

Dreikorn, M.J. (2004). The synergy of one. Creating high-performing sustainable organisations through integrated performance leadership. ASQ Quality Press, Milwaukee

Easterby-Smith, M., M.A. Lyles, \& M.A. Peteraf (2009). Dynamic capabilities: current debates and future directions. British Journal of Management, 20: S1-S8. http://dx.doi.org/10.1111/j.1467-8551.2008.00609.x

Flatters, P. en Willmott, M. (2009), Understanding the post-recession consumer, Harvard Business Review, July-August, pp. 106-112

Foster, R., \& S. Kaplan. (2001). Creative destruction. Why companies that are built to last underperform the market - and how to successfully transform them. Doubleday, New York

Freeman, E. \& M. Zollo (2009). Re-thinking the firm in a post-crisis world. Special issue call for papers, European Management Review

Geus, A. de. (1997). The living company. Habits for survival in a turbulent environment. Longview Publishing, London

Glaister, K.W. \& Buckley, P.J. (1998). Measures of performance in UK international $\begin{array}{lllll}\text { alliances. } & \text { Organisation } & \text { Studies, } & 19, & 1 \text { : }\end{array}$ http://dx.doi.org/10.1177/017084069801900105

Goranson, H.T. (1999). The agile virtual enterprise. Cases, metrics and tools. Quorum Books, Westport

Gottfredson, M., \& S. Schaubert. (2008). The breakthrough imperative, how the best managers get outstanding results. HarperCollins, New York

Gratton, L. (2004). The democratic enterprise. Liberating your business with freedom, flexibility and commitment. Prentice Hall Financial Times, Harlow

Guth, W.D. (2009), Developing new avenues for growth: challenges presented by five trends in the global environment, Journal of International Management, 15, pp. 252-261. http://dx.doi.org/10.1016/j.intman.2008.12.003

Haeckel, S.H. (1999). Adaptive enterprise. Creating and leading sense-and-respond organisations. Harvard Business School Press, Boston.

Hagel III, J. Brown, J.S. en Davison, L. (2009), The big shift, measuring the forces of change, Harvard Business Review, July-August, pp. 86-89 
Hair, J. F., Anderson, R.E., Tatham, R.L. \& Black, W.C. (1998). Multivariate Data Analysis, New Jersey: Prentice-Hall.

Hales, C. P. (1999). Leading horses to water? The impact of decentralization on managerial behavior. Journal of Management Studies, 36, 6, 831-51. http://dx.doi.org/10.1111/1467-6486.00160

Hales, C. P., \& Mustapha, N. (2000). Commonalities and variations in managerial work: a study of middle managers in Malaysia. Asia Pacific Journal of Human Resources, 38, 1, 731-56. http://dx.doi.org/10.1177/103841110003800102

Hales, C. P., \& Tamangani, Z. (1996). An investigation of the relationship between organisational structure, managerial role expectations and managers' work activities'.

Heap, J., \& Bolton, M. (2004). Using perceptions of performance to drive business improvement. In Neely, A., M. Kennerly, \& A. Waters (Eds.), Performance measurement and management: public and private, Centre for Business Performance, Cranfield University, pp. 1085-1090

Hess, E.D. ,\& R.K. Kazanjian (eds.) (2006). The search for organic growth. Cambridge University Press

Hodgetts, R.M. (1998). Measures of quality \& high performance. Simple tools and lessons learned from America's most successful corporations. Amacom, New York

Hofstede, G. (1980). Culture's Consequences: International differences in work-related values. Thousand Oaks: Sage Publications

Humprey, C., \& R. Scapens (1992). Theories and case studies: limitation or liberation (or a case of accounting theory not becoming what it was not). Working Paper 92/4, University of Manchester, Manchester

Jack, E.P., \& A.S. Raturi (2006). Lessons learned from methodological triangulation in management research. Management Research News, 29, 6: 345-357. http://dx.doi.org/10.1108/01409170610683833

Jayakody, J.A.S.K. (2008). Charismatic leadership in Sri Lankan business organisations. Journal of Management Development, 27, 5: 480-498. http://dx.doi.org/10.1108/02621710810871808

Jing, F.F., \& G.C. Avery (2008). Missing links in understanding the relationship between leadership and organisational performance. International Business \& Economics Research Journal, 7, 5: 67-78

Kamdar, M. (2007). Planet India. How the fastest growing democracy is transforming America and the world. Scribner, New York

Kelly, E. (2006), Powerful Times, rising to the challenge of our uncertain world, Wharton School Publishing, Upper Saddle River

King, W.R., \& J. He (2005). Understanding the role and methods of meta-analysis in IS research. Communications of the Association for Information Systems, 16: 665-686

Kotler, P., \& Caslione, J.A. (2009), Chaotics, the business of managing and marketing in the age of turbulence, Amacom, New York 
Kotter, J. P., \& J. L. Heskett (1992). Corporate culture and performance. Free Press, New York

Lamond, D., P.E. Spector, G. McDonald, R. Wu, \& B. Hosking (2001). Of emics and etics: the development of a cross-cultural facet measure of job satisfaction. Academy of Management Proceedings 2001 HR: B1-B6

Lawler III, E.E., S.A. Mohrman, \& G.E. Ledford Jr. (1998). Strategies for high performance organisations - The CEO report. Jossey-Bass Publishers, San Francisco

Lawrence, P. (2002). The change game. How today's global trends are shaping tomorrow's companies. Kogan Page, London

Lee, A.S. \& R.L. Baskerville (2003). Generalizing generalizability in information systems research. Information Systems research, 14, 3: 221-243. http://dx.doi.org/10.1287/isre.14.3.221.16560

Light, P.C. (2005). The four pillars of high performance. How robust organisations achieve extraordinary results. McGraw-Hill, New York

Lockett, A., S. Thompson, \& U. Morgenstern (2009). The development of the resource-based view of the firm: a critical appraisal. International Journal of Management Reviews, 11, 1: 9-28. http://dx.doi.org/10.1111/j.1468-2370.2008.00252.x

Malone, T.W. (2003). Is empowerment just a fad? Control, decision making and IT. In: Malone, T.W., R. Laubacher \& M.S. Scott Morton (Eds). Inventing the organisations of the $21^{\text {st }}$ century. The MIT Press, Cambridge; Bakker et al. (2004)

Manzoni, J.F. (2004). From high performance organisations to an organisational excellence framework. In: Epstein, M.J. \& J.F. Manzoni (Eds). Performance measurement and management control: superior organisational performance. Studies in managerial and financial accounting, volume 14, Elsevier, Amsterdam

Martin, C. (2002). Managing for the short term. The new rules for running a business in a day-to-day world. Currency Doubleday, New York.

Martin, J., M.S. Feldman, M.J. Hatch \& S.B. Sitkin (1983). The uniqueness paradox in organisational stories. Administrative Science Quarterly, 28, September: 438-453. http://dx.doi.org/10.2307/2392251

Matear, S., B.J. Gray, \& T. Garrett (2004). Market orientation, brand investment, new service development, market position and performance for service organisations. International Journal of Service Industry Management, 15, 3: 284-301. http://dx.doi.org/10.1108/09564230410540944

McGee, K.G. (2004). Heads up. How to anticipate business surprises and seize opportunities first. Harvard Business School Press, Boston

Milgrom, P., \& J. Roberts (1990). The economics of modern manufacturing: technology, strategy, and organization. American Economic Review, 80, 3: 511-528

Milgrom, P., \& J. Roberts (1995). Complementaries and fit: strategy, structure, and organizational change in manufacturing. Journal of Accounting and Economics, 19, 2-3: 179-208

Mintzberg, H. (1973). The nature of managerial work. Harper \& Row, New York 
Mintzberg, H. (2009). Managing. Financial Times Prentice Hall, Harrow

Mische, M.A. (2001). Strategic renewal. Becoming a high-performance organisation. Prentice Hall, Upper Saddle River, New Jersey

Morris, M.W., K. Leung, D. Ames, \& B. Lickel (1999). Views from inside and outside: integrating emic and etic insights about culture and justice judgment. Academy of Management Review, 24, 4: 781-796

Morrison, A.J. (2000). Developing a global leadership model. Human Resource Management, 39 , 2\&3:

117-131. http://dx.doi.org/10.1002/1099-050X(200022/23)39:2/3<117::AID-HRM3>3.0.CO;2-1

Morton, C. (2003). By the skin of our teeth. Creating sustainable organisations through people. Middlesex University Press, London

Nath, K. (2008). India's century. The age of entrepreneurship in the world's biggest democracy. McGraw-Hill, New York

Niendorf, B., \& K. Beck (2008). Good to Great, or Just Good? Academy of Management Perspectives, 22, 4: 13-20. http://dx.doi.org/10.5465/AMP.2008.35590350

Nobrega, W., \& A. Sinha (2008). Riding the Indian tiger. Understanding India - the world's fastest growing market. John Wiley \& Sons, Hoboken

O’Reilly III, C.A., \& J. Pfeffer (2000). Hidden value. How great companies achieve extraordinary results with ordinary people. Harvard Business School Press, Boston

Pal, N. \& D.C. Pantaleo (Eds). (2005). The agile enterprise, reinventing your organisation for success in an on-demand world. Springer Science + Business Media, New York

Palrecha, R. (2009). Leadership - universal or culturally-contingent - a multi-theory/multi-method test in China. Academy of Management Proceedings: 1-6

Pearson, A.W., J.C. Carr, \& J.C. Shaw (2008). Toward a theory of familiness: a social capital perspective. Entrepreneurship Theory and Practice, 32, 6: 949-969. http://dx.doi.org/10.1111/j.1540-6520.2008.00265.x

Peteraf, M.A., \& J.B. Barney (2003). Unravelling the resource-based tangle. Managerial and Decision Economics, 24: 309-323. http://dx.doi.org/10.1002/mde.1126

Peters, T., \& R. Waterman (1982). In Search Of Excellence. Warner Books, New York

Podsakoff, P.M., Mackenzie, S.B., Lee, J.Y., \& Podsakoff, N.P. (2003). 'Common method bias in behavioral research: a critical review of the literature and recommended remedies'. Journal of Applied Psychology, 88, 879-903. http://dx.doi.org/10.1037/0021-9010.88.5.879

Porras, J., S. Emery, \& M. Thompson (2007). Success built to last. Wharton School Publishing, Harlow

Quinn, J.B. (2005). The intelligent enterprise, a new paradigm. Academy of Management Executive, 19, 4: 109-121. http://dx.doi.org/10.5465/AME.2005.19417913

Ramamurti, R., \& J.V. Singh (Eds) (2009). Emerging multinationals in emerging markets. Cambridge University Press, Cambridge

Resnick, B.G., \& T.L. Smunt (2008). From Good to Great to . . . Academy of Management Perspectives, 22, 4: 6-12. http://dx.doi.org/10.5465/AMP.2008.35590349 
Rosen, R. (2000). Global literacies. Lessons on business leadership and national cultures. Simon \& Schuster. New York

Sadler, P. (2002). Building tomorrow's company. A guide to sustainable business success. Kogan Page, London

Schuster, C.P., \& M.J. Copeland (2006). Global business practices, adapting for success. Thomson/South-Western, Mason

Scott Morton, M.S. (2003). The interesting organisations project: digitalization of the $21^{\text {st }}$ century firm. In: Malone, T.W., R. Laubacher \& M.S. Scott Morton (Eds). Inventing the organisations of the $21^{\text {st }}$ century. The MIT Press, Cambridge, Mass

Shao, L., \& Webber, S. (2006). A cross-cultural test of the five-factor model of personality and transformational leadership. Journal of Business Research, 59: 936-944. http://dx.doi.org/10.1016/j.jbusres.2006.02.005

Simons, T. (2008). The integrity dividend, leading by the power of your word. Jossey-Bass, San Francisco

Sirkin, H.L., J.W. Hemerling, \& A.K. Bhattacharya (2008). Globality, competing with everyone from everywhere for everything. Headline Business Plus, London

Spear, S.J. (2009). Chasing the rabbit, how market leaders outdistance the competition and how great companies can catch up and win. McGraw-Hill, London

Srnka, K.J., \& S.T. Koeszegi (2007). From words to numbers: how to transform qualitative data into meaningful quantitative results. Schmalenbach Business Review (SBR), 59, 1: 29-57

Stadler, C. (2007). The 4 principles of enduring success. Harvard Business Review, July-August: 62-72

Starbuck, W.H. (2005). Four great conflicts of the twenty-first century. In: Cooper, C.L. (Ed). Leadership and management in the $21^{\text {st }}$ century. Business challenges of the future. Oxford University Press, Oxford

Stede, W.A. van der (2003). The effect of national culture on management control and incentive system design in multi-business firms: evidence of intracorporate isomorphism. European Accounting Review, 12, 263-285. http://dx.doi.org/10.1080/0963818022000009859

Strebel, P. (2003). Trajectory management, leading a business over time. John Wiley \& Sons, Chichester

Tappin, S., \& A. Cave (2008). The secrets of CEOs. Nicholas Brealey Publishing, London Teece, D.J. (2009). Dynamic capabilities \& strategic management, organizing for innovation and growth. Oxford University Press, Oxford.

Tengblad, S. (2000). Continuity and change in managerial work. GRI Report 2000:3, Götenburg Research Institute, Götenburg University, School of Business, Economics and Law

Tengblad, S. (2006). Is there a 'new managerial work'? A comparison with Henry Mintzberg’s classic study 30 years later. Journal of Management Studies, 43, 7: 1437-1461. http://dx.doi.org/10.1111/j.1467-6486.2006.00651.x 
Thoenig, J.C. \& C. Waldman (2007). The marking enterprise, business success and societal embedding. Insead Business Press/Palgrave MacMillan, Basingstoke

Tolmie, P., Hughes, J., Rouncefield, M., \& Sharrock, W. (2003). The 'Virtual' Manager?: change and continuity in managerial work. Paper, Department of Sociology, Lancaster University, Lancaster

Volberda, H.W. (1998). Building the flexible firm. How to remain competitive. Oxford University Press, Oxford.

Waal, A.A. de (2004). Stimulating performance-driven behaviour to obtain better results. International Journal of Productivity and Performance Management, 53, 4: 301-316. http://dx.doi.org/10.1108/17410400410533890

Waal, A.A. de (2012). What makes a high performance organization, five validated factors of competitive performance that apply worldwide, Global Professional Publishing, Enfield

Wall, T.D., Mitchie, J., Patterson, M., Wood, S.J., Sheeran, M., Clegg, C.W., \& West, M. (2004). On the validity of subjective measures of company performance. Personnel Psychology, 57: 95-118. http://dx.doi.org/10.1111/j.1744-6570.2004.tb02485.x

Watson, T. J. (2001). In Search of Management. London: Routledge

Weick, K.E. \& K.M. Sutcliffe (2001). Managing the unexpected. Assuring high performance in an age of complexity. Jossey-Bass, San Francisco.

Zagersek, H., M. Jaklic, \& S.J. Stough. (2004). Comparing leadership practices between the United States, Nigeria, and Slovenia: does culture matter? International Journal of Cross Cultural Management, 11, 2: 16-34. http://dx.doi.org/10.1108/13527600410797774

Zook, C. \& J. Allen (2001). Profit from the core. Growth strategy in an era of turbulence. Harvard Business Press, Boston

\section{Appendix 1. Example of the identification process of the HPO characteristics}

This appendix gives the detailed scores for the Design factor of the ordering framework. Each HPO characteristic in a factor is composed of elements which have been identified from the literature. This appendix lists all the elements for each literature study category (A, B and C). The numbers in columns ' $A$ ', ' $B$ ' and ' $C$ ' refer to the studies from which the elements were taken (see Appendix 1). To weigh the elements, each element from study category A gets 6 points, $\mathrm{B}$ and $\mathrm{C}$ get 3 and 1 points respectively. The 'Total score' column shows the total score for all the elements which have been grouped under a particular HPO-characteristic. There are 105 category A-studies, 66 category B-studies and 119 category C-studies, which gives a maximum score for a characteristic of $(105 \times 6)+(66 \times 3)+(119 \times 1)=947$ points. This score would be reached when all of the 290 studies contained an element which is grouped under the characteristic under consideration. The '\% of total' column shows the total score divided by 947 to give the weighted percentage of the literature sources in which the particular HPO-characteristic can be found. A score of 100 percent would be reached when the underlying elements of the characteristic would occur in all sources. The score gives an indication of the importance of the characteristic for becoming a HPO. Finally, the ' $\%$ of sources' column shows the percentage of different sources the element is found in (this is the numbers in columns A, B and C added up without double-counting, in the 'Total sources' 
column) divided by the total number of literature sources (290). This is a measurement of the frequency of occurrence in the literature of the specific characteristic.

\begin{tabular}{|c|c|c|c|c|c|c|c|}
\hline & $\mathbf{A}$ & B & $\mathbf{C}$ & $\begin{array}{l}\text { Total } \\
\text { score } \\
\end{array}$ & $\begin{array}{l}\% \text { of } \\
\text { total } \\
\end{array}$ & $\begin{array}{c}\text { Total } \\
\text { sources }\end{array}$ & $\begin{array}{c}\% \text { of } \\
\text { sources } \\
\end{array}$ \\
\hline \multicolumn{8}{|l|}{ Design characteristics } \\
\hline $\begin{array}{l}\text { Stimulate cross-functional } \\
\text { and cross-organisational } \\
\text { collaboration }\end{array}$ & $\begin{array}{c}15,15,16 \\
19,22,22, \\
22,24,30 \\
33,34,122, \\
125,129 \\
132,132 \\
137,158 \\
165,234 \\
234\end{array}$ & $\begin{array}{l}42,47 \\
50,51, \\
51,53 \\
55,139 \\
263 \\
263 \\
266\end{array}$ & $\begin{array}{l}64,64,66 \\
71,80,86, \\
149,154, \\
186,195 \\
195,205 \\
216,224 \\
224,273, \\
277,280\end{array}$ & 177 & 18.7 & 40 & 13.8 \\
\hline $\begin{array}{l}\text { Simplify and flatten the } \\
\text { organisation by reducing } \\
\text { boundaries and barriers } \\
\text { between and around units }\end{array}$ & $\begin{array}{c}5,5,18,18 \\
22,22,26 \\
27,31,34 \\
34,97,132 \\
135,137 \\
234,241 \\
255\end{array}$ & $\begin{array}{c}51,53 \\
54,59 \\
60,60, \\
61,167 \\
170 \\
258 \\
265\end{array}$ & $\begin{array}{l}77,78,78, \\
87,217 \\
225,227 \\
286\end{array}$ & 149 & 15.7 & 31 & 10.7 \\
\hline $\begin{array}{l}\text { Foster organisation-wide } \\
\text { information, knowledge and } \\
\text { best practices sharing }\end{array}$ & $\begin{array}{c}6, \overline{10}, \overline{17}, \overline{22} \\
25,26,34 \\
122,129\end{array}$ & $\begin{array}{l}44, \overline{,} 5 \\
50,55 \\
61,145\end{array}$ & $\begin{array}{c}\overline{79}, \overline{79}, 83, \\
118,195\end{array}$ & - & -- & - & 6.2 \\
\hline $\begin{array}{l}\text { Constantly realign the } \\
\text { business with changing } \\
\text { internal and external } \\
\text { circumstances }\end{array}$ & $\begin{array}{c}5,22,23,33 \\
34,127\end{array}$ & $\begin{array}{c}2,51, \\
61,146, \\
260 \\
261 \\
\end{array}$ & $\begin{array}{c}81,82,87 \\
149,198 \\
289\end{array}$ & 60 & 6.3 & 18 & 6.2 \\
\hline $\begin{array}{l}\text { Create a sense of ownership } \\
\text { and entrepreneurial feel by } \\
\text { establishing an integrated } \\
\text { network of small } \\
\text { decentralized units }\end{array}$ & $2,136,166$ & $\begin{array}{c}55,55 \\
55,57 \\
57,59 \\
268\end{array}$ & $\begin{array}{c}62,71,79 \\
87,118 \\
192,204 \\
204\end{array}$ & 47 & 5.0 & 14 & 4.8 \\
\hline $\begin{array}{l}\text { Stimulate support functions to } \\
\text { be integrated business } \\
\text { partners }\end{array}$ & $\begin{array}{c}22,96,119 \\
241\end{array}$ & 44 & 65,75 & 29 & 3.1 & 7 & 2.4 \\
\hline $\begin{array}{l}\text { Create an infrastructure that } \\
\text { supports the strategy and the } \\
\text { value drivers }\end{array}$ & 24 & $\begin{array}{l}42,44 \\
262 \\
262\end{array}$ & $\begin{array}{c}81,83,86 \\
100,185 \\
187,197 \\
199,219 \\
277 \\
\end{array}$ & 28 & 3.0 & 14 & 4.8 \\
\hline $\begin{array}{l}\text { Implement a dynamic } \\
\text { organisational design to }\end{array}$ & $3,34,127$ & & $\begin{array}{c}85,87,157 \\
192,216\end{array}$ & 23 & 2.4 & 8 & 2.8 \\
\hline
\end{tabular}




\begin{tabular}{|l|c|c|c|c|c|c|c|}
\hline enhance flexibility & & & & & & \\
\hline Establish a consistent & & 48,59, & $62,77,77$, & & & & \\
responsibility structure with & & $\begin{array}{r}61, \\
77,77,77,\end{array}$ & 21 & $\mathbf{2 . 2}$ & 9 & 3.1 \\
clear roles and & & 144 & $80,85,205$ & & & & \\
accountabilities & & & & & & \\
\hline Think in matrixes & 22 & 55 & 201 & 10 & $\mathbf{1 . 1}$ & 3 & 1.0 \\
\hline Manage a virtual organisation & & 172 & & 3 & $\mathbf{0 . 3}$ & 1 & 0.3 \\
\hline
\end{tabular}

N.B. The dotted line denotes the selection point (9 percent or higher) of the characteristics which are taken forward in the empirical study. 
Appendix 2. Detailed information on the respondents and their organisations (research Phase 2b)

This appendix provides information on the respondents (2015 from 1470 organisations) participating in the questionnaire as applied during the HPO research Phase $2 \mathrm{~b}$.

\begin{tabular}{|l|c|}
\hline Country & $\mathbf{\%}$ \\
\hline Netherlands & 50.9 \\
\hline Surinam & 6.3 \\
\hline Spain & 4.9 \\
\hline Italy & 4.3 \\
\hline Russia & 4.2 \\
\hline Germany & 3.8 \\
\hline UK & 3.1 \\
\hline Belgium & 2.4 \\
\hline Vietnam & 2.2 \\
\hline Swiss & 1.8 \\
\hline France & 1.7 \\
\hline Peru & 1.0 \\
\hline USA & 1.0 \\
\hline Tanzania & 0.8 \\
\hline Uganda & 0.1 \\
\hline Poland & 0.1 \\
\hline Nepal & 0.1 \\
\hline Ghana & 0.1 \\
\hline Bhutan & 0.1 \\
\hline Rwanda & 0.1 \\
\hline Indonesia & 0.1 \\
\hline Ethiopia & 0.1 \\
\hline Zambia & 0.3 \\
\hline Philippines & 0.1 \\
\hline Argentina & 0.1 \\
\hline Thailand & 0.1 \\
\hline India & 0.1 \\
\hline Palestine & 0.1 \\
\hline Sri Lanka & 0.1 \\
\hline Kenya & 0.1 \\
\hline Georgia & 0.1 \\
\hline Yemen & 0.1 \\
\hline Bolivia & 0.1 \\
\hline Namibia & 0.1 \\
\hline Taiwan & 0.1 . \\
\hline
\end{tabular}

\begin{tabular}{|l|c|}
\hline Industry & \% \\
\hline Public sector & 12.6 \\
\hline Financial Services & 10.3 \\
\hline Healthcare & 9.3 \\
\hline ICT & 9.0 \\
\hline Manufacturing & 5.3 \\
\hline Education & 4.0 \\
\hline Unknown & 3.8 \\
\hline Consultancy & 3.1 \\
\hline Construction & 2.7 \\
\hline Transport & 2.0 \\
\hline FMCG & 1.4 \\
\hline Retail & 0.8 \\
\hline Food & 0.8 \\
\hline Pharmacy & 0.7 \\
\hline Telecom & 0.7 \\
\hline Professional Services & 0.3 \\
\hline Other & 33.0 \\
\hline
\end{tabular}

Percentage of respondents per industry 


\begin{tabular}{|l|c|} 
Denmark & 0.05 \\
\hline Armenia & 0.05 \\
\hline Jordania & 0.05 \\
\hline Nigeria & 0.05 \\
\hline Zimbabwe & 0.05 \\
\hline Pakistan & 0.02 \\
\hline Burkina Faso & 0.02 \\
\hline Ecuador & 0.02 \\
\hline Honduras & 0.02 \\
\hline Malawi & 0.02 \\
\hline Mexico & 0.01 \\
\hline China & 0.01 \\
\hline South Korea & 0.01 \\
\hline Austria & 0.01 \\
\hline Colombia & 0.01 \\
\hline Cambodia & 0.01 \\
\hline Unknown & 1.7 \\
\hline Percenge
\end{tabular}

Percentage of respondents per country

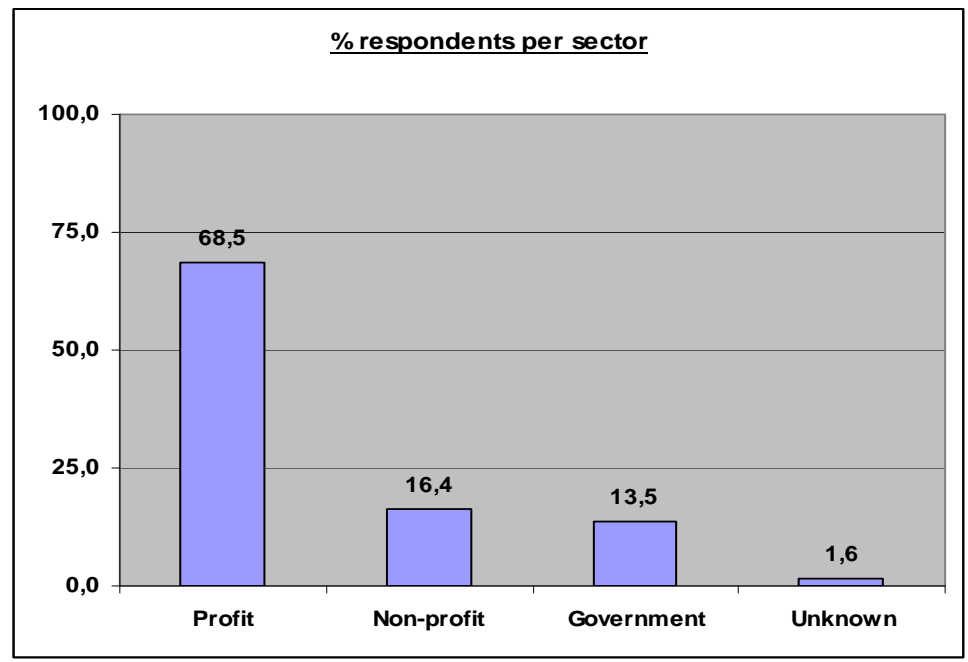

Figure 1. Percentage of responding organisations per sector 


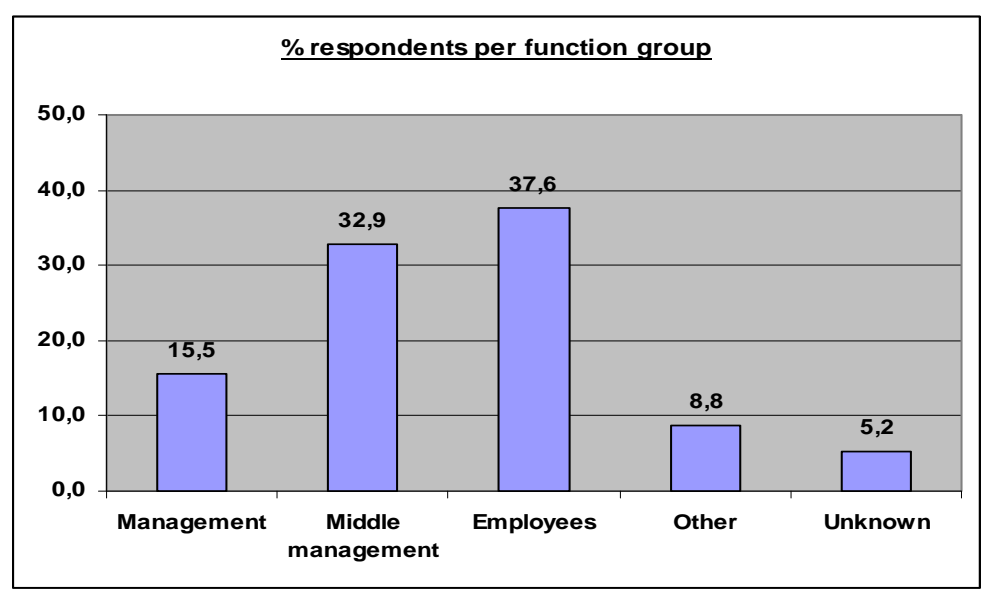

Figure 2. Percentage respondents per function group

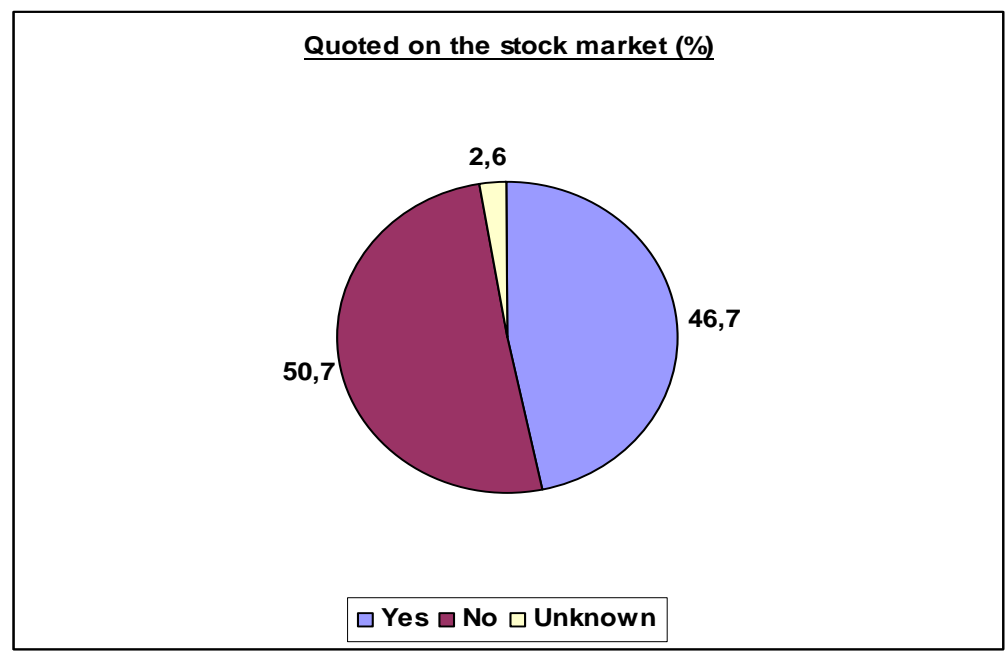

Figure 3. Percentage of organisations quoted on the stock market

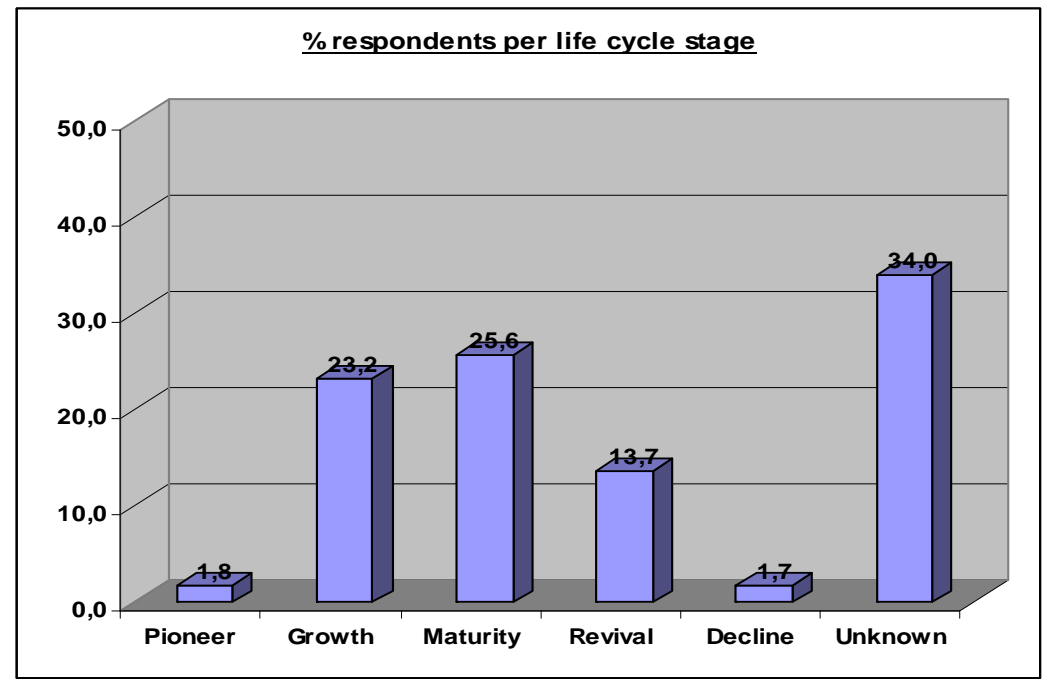

Figure 4. Percentage of organisations per life cycle stage 
Appendix 3. Pattern matrix of the HPO characteristics and factors

\begin{tabular}{|c|c|c|c|c|c|c|c|}
\hline \multirow[b]{2}{*}{ No } & \multirow[b]{2}{*}{ Characteristic } & \multicolumn{6}{|c|}{ Factor } \\
\hline & & 1 & 2 & 3 & 4 & 5 & 6 \\
\hline 1 & $\begin{array}{l}\text { The organisation has a flat structure: there are few } \\
\text { hierarchical layers. }\end{array}$ & .162 & .020 & -.027 & .104 & -.506 & -.007 \\
\hline 2 & $\begin{array}{l}\text { In the organisation people of different } \\
\text { organisational units can easily cooperate. }\end{array}$ & .116 & .039 & .037 & .178 & -.429 & .230 \\
\hline 3 & $\begin{array}{l}\text { The management of the organisation allows } \\
\text { experiments. }\end{array}$ & -.024 & .288 & .108 & .145 & -.478 & .044 \\
\hline 4 & The organisation has an open culture. & .140 & .143 & .178 & .047 & -.495 & .198 \\
\hline 5 & $\begin{array}{l}\text { In the organisation organisational members have } \\
\text { the freedom to decide and act. }\end{array}$ & .025 & .262 & .104 & -.028 & -.583 & .175 \\
\hline 6 & $\begin{array}{l}\text { The organisation has adopted a strategy that sets it } \\
\text { clearly apart from other organisations. }\end{array}$ & .169 & .002 & .083 & .408 & -.071 & .072 \\
\hline 7 & $\begin{array}{l}\text { In the organisation processes are continuously } \\
\text { improved. }\end{array}$ & -.001 & .049 & .005 & .807 & -.036 & -.046 \\
\hline 8 & $\begin{array}{l}\text { In the organisation processes are continuously } \\
\text { simplified. }\end{array}$ & -.055 & -.021 & -.057 & .845 & -.124 & -.042 \\
\hline 9 & $\begin{array}{l}\text { In the organisation processes are continuously } \\
\text { aligned. }\end{array}$ & .055 & -.046 & -.020 & .840 & -.048 & -.062 \\
\hline 10 & $\begin{array}{l}\text { In the organisation everything that matters to the } \\
\text { organisation's performance is explicitly reported. }\end{array}$ & .279 & .038 & .010 & .488 & .147 & .055 \\
\hline 11 & $\begin{array}{l}\text { In the organisation both financial and non-financial } \\
\text { information is reported to organisational members. }\end{array}$ & .173 & .175 & .029 & .342 & -.027 & -.022 \\
\hline 12 & $\begin{array}{l}\text { The management of the organisation frequently } \\
\text { engages in a dialogue with employees. }\end{array}$ & .121 & .641 & .009 & .106 & -.095 & -.224 \\
\hline 13 & $\begin{array}{l}\text { Organisational members spend much time on } \\
\text { communication, knowledge exchange and learning. }\end{array}$ & -.057 & .570 & -.008 & .238 & -.017 & .092 \\
\hline 14 & $\begin{array}{l}\text { Organisational members are always involved in } \\
\text { important processes. }\end{array}$ & .027 & .592 & -.031 & .230 & -.128 & -.091 \\
\hline 15 & $\begin{array}{l}\text { The management of the organisation is trusted by } \\
\text { organisational members. }\end{array}$ & .557 & -.018 & .170 & .180 & -.212 & -.084 \\
\hline 16 & The management of the organisation has integrity. & .553 & .052 & .204 & .055 & -.269 & -.158 \\
\hline 17 & $\begin{array}{l}\text { The management of the organisation is a role } \\
\text { model for organisational members. }\end{array}$ & .583 & .055 & .175 & .121 & -.250 & -.170 \\
\hline 18 & $\begin{array}{l}\text { The management of the organisation applies fast } \\
\text { decision making. }\end{array}$ & .805 & -.073 & -.052 & .093 & -.109 & -.089 \\
\hline 19 & $\begin{array}{l}\text { The management of the organisation applies fast } \\
\text { action taking. }\end{array}$ & .774 & -.013 & -.062 & .098 & -.134 & -.054 \\
\hline 20 & $\begin{array}{l}\text { The management of the organisation coaches } \\
\text { organisational members to achieve better results. }\end{array}$ & .506 & .044 & .008 & .254 & -.065 & .077 \\
\hline 21 & The management of the organisation focuses on & .572 & .123 & .136 & -.003 & .256 & .153 \\
\hline
\end{tabular}




\begin{tabular}{|c|c|c|c|c|c|c|c|}
\hline \multirow[b]{2}{*}{ No } & \multirow[b]{2}{*}{ Characteristic } & \multicolumn{6}{|c|}{ Factor } \\
\hline & & 1 & 2 & 3 & 4 & 5 & 6 \\
\hline & achieving results. & & & & & & \\
\hline 22 & $\begin{array}{l}\text { The management of the organisation is very } \\
\text { effective. }\end{array}$ & .497 & .353 & .062 & .092 & .107 & -.063 \\
\hline 23 & $\begin{array}{l}\text { The management of the organisation applies strong } \\
\text { leadership. }\end{array}$ & .711 & .003 & .111 & .034 & .024 & .062 \\
\hline 24 & The management of the organisation is confident. & .615 & .092 & .152 & .036 & .015 & .032 \\
\hline 25 & $\begin{array}{l}\text { The management of the organisation is decisive } \\
\text { with regard to non-performers. }\end{array}$ & .534 & .021 & -.137 & .015 & .000 & .353 \\
\hline 26 & $\begin{array}{l}\text { The management of the organisation allows making } \\
\text { mistakes. }\end{array}$ & -.050 & .567 & .032 & -.219 & -.204 & -.106 \\
\hline 27 & $\begin{array}{l}\text { The management of the organisation inspires } \\
\text { organisational members to accomplish } \\
\text { extraordinary results. }\end{array}$ & -.070 & -.247 & -.098 & -.036 & -.078 & .638 \\
\hline 28 & $\begin{array}{l}\text { Organisational members are trained to be resilient } \\
\text { and flexible. }\end{array}$ & .136 & .036 & .011 & .178 & -.170 & .492 \\
\hline 29 & $\begin{array}{l}\text { The management of the organisation welcomes } \\
\text { change. }\end{array}$ & .030 & .755 & -.075 & .064 & -.008 & .020 \\
\hline 30 & The organisation is performance driven. & .320 & .562 & .052 & -.041 & .283 & .161 \\
\hline 31 & $\begin{array}{l}\text { The management of the organisation always holds } \\
\text { organisational members responsible for their } \\
\text { results. }\end{array}$ & .476 & .027 & -.029 & -.084 & .107 & .390 \\
\hline 32 & $\begin{array}{l}\text { New employees are selected on their ability to fit in } \\
\text { with the organisational culture. }\end{array}$ & .259 & .153 & .113 & .028 & -.196 & .293 \\
\hline 33 & $\begin{array}{l}\text { The organisation has a diverse and complementary } \\
\text { management team. }\end{array}$ & .305 & .086 & .124 & .082 & -.170 & .223 \\
\hline 34 & $\begin{array}{l}\text { The organisation has a diverse and complementary } \\
\text { workforce. }\end{array}$ & .156 & .122 & .145 & .033 & -.099 & .372 \\
\hline 35 & The organisation excels in its core competencies. & .150 & .055 & .216 & .281 & .017 & .345 \\
\hline 36 & $\begin{array}{l}\text { The organisation continuously innovates its core } \\
\text { competencies. }\end{array}$ & .126 & .128 & .172 & .406 & .044 & .290 \\
\hline 37 & $\begin{array}{l}\text { The organisation continuously innovates its } \\
\text { products, processes and services. }\end{array}$ & .070 & .161 & .186 & .421 & .136 & .247 \\
\hline 38 & $\begin{array}{l}\text { The organisation maintains good and long-term } \\
\text { relationships with all stakeholders. }\end{array}$ & .073 & .037 & .413 & .297 & -.032 & .105 \\
\hline 39 & $\begin{array}{l}\text { The organisation is aimed at servicing the } \\
\text { customers as best as possible. }\end{array}$ & .071 & .097 & .349 & .246 & .048 & .245 \\
\hline 40 & $\begin{array}{l}\text { The organisation explicitly chooses to compare } \\
\text { itself with the best in the market place/industry. }\end{array}$ & .035 & .188 & .340 & .223 & .255 & .316 \\
\hline 41 & $\begin{array}{l}\text { The organisation grows through partnerships with } \\
\text { suppliers and/or customers. }\end{array}$ & -.039 & .195 & .359 & .093 & .085 & .353 \\
\hline 42 & The management of the organisation has been with & .042 & -.171 & .775 & -.134 & .004 & -.042 \\
\hline
\end{tabular}




\begin{tabular}{|c|l|c|c|c|c|c|c|}
\hline \multicolumn{2}{|c|}{} & \multicolumn{5}{c|}{ Factor } \\
\hline No & Characteristic & $\mathbf{1}$ & $\mathbf{2}$ & $\mathbf{3}$ & $\mathbf{4}$ & $\mathbf{5}$ & $\mathbf{6}$ \\
\hline 43 & $\begin{array}{l}\text { New management is promoted from within the } \\
\text { the company for a long time. }\end{array}$ & .008 & .029 & $\mathbf{. 6 8 8}$ & -.016 & .028 & -.073 \\
\hline 44 & $\begin{array}{l}\text { The organisation is a secure workplace for } \\
\text { organisational members. }\end{array}$ & -.055 & -.012 & $\mathbf{. 6 9 5}$ & .067 & -.169 & -.073 \\
\hline
\end{tabular}

(Principal component analysis, oblimin with Kaiser normalization, rotation converged in 21 iterations) 